Psychological Medicine, 1988, 18, 529-533

Printed in Great Britain

\title{
EDITORIAL
}

\section{Polymorphic DNA markers and mental disease ${ }^{1}$}

The remarkable recent advances in molecular genetics are grounds for considerable optimism in psychiatry, where many diseases appear to have an hereditary component. Most notably, the discovery of restriction fragment-length polymorphisms (RFLPs) has greatly increased the number of markers available for linkage studies.

Linkage analysis has two basic requirements. First, co-operative families must be ascertained in which several people are affected by the condition under study. Secondly appropriate genetic markers must be available. These should be reliably detected and polymorphic, that is to say, present in two or more common forms in the population. These are studied in the families, in the hope that one variant of the polymorphism will segregate with the illness in that family, i.e. be present in affected, but not unaffected, members more often than would be expected by chance. If this happens, it suggests that the locus coding for the marker and the pathological gene are close enough on the same chromosome to render separation during meiosis (recombination) unlikely. The frequency of recombination is, therefore, a measure of the distance separating the two loci.

Until the discovery of RFLPs the applicability of this potentially powerful technique was limited by the fact that few suitable polymorphic markers were available. Restriction enzymes cut DNA (which can be obtained quite easily from peripheral blood leucocytes) where specific base sequences occur in the molecule and result in a number of small, easily manageable pieces. These can then be separated according to size by electrophoresis. The positions of the sites that are cut by a given restriction enzyme vary from one individual to another, apart from the special case of identical twins. Thus, the fragments produced from the digestion of one individual's DNA by a given restriction enzyme will differ from those produced by its action on DNA from someone else. These polymorphisms are inherited in a simple Mendelian fashion. Variations in length of specific restriction fragments (RFLPs), can be detected after electrophoresis by adding a quantity of small, identical pieces of single-stranded DNA that have been radio-labelled. Single-stranded DNA will hybridize, in other words combine to form a double strand, with another single strand composed of complementary base sequences. Such 'gene probes' therefore recognize and label complementary sequences, and their application to DNA that has been cut with a restriction enzyme and denatured to a single strand allows detection of any RFLPs that are close to the labelled DNA on the genome.

'Candidate genes' whose involvement in the disease is suspected a priori may be used as probes. For example, genes coding for various enzymes involved in the monoamine neurotransmitter systems might be relevant to psychiatric disorders. Another strategy is to concentrate attention upon probes that label a particular part of the genome, such as a single chromosome, when the disease gene is believed to be located in that area. Unknown pieces of DNA selected at random may also be used as probes and their identities and position in the human genome determined only if linkage is established. It was this technique that Gusella et al. (1983) employed successfully to locate the gene for Huntington's disease on chromosome 4.

The excitement generated by findings in Huntington's disease was tempered for psychiatrists by the realization that none of the common psychiatric disorders show such a clear and unambiguous pattern of inheritance. However, recent work on both Alzheimer's disease and affective disorder has removed many of the doubts about the extent to which molecular genetics will be applicable to the study of mental illness.

\footnotetext{
' Address for correspondence: Dr M. J. Owen, Department of Biochemistry and Molecular Genetics, St Mary's Hospital Medical School, London W2 IPG.
} 


\section{ALZHEIMER'S DISEASE}

The existence of several large families in which Alzheimer's disease (AD) appears to be segregating as an autosomal dominant suggested that the disease might be amenable to genetic analysis using RFLP linkage techniques. Furthermore, associations between Down's syndrome and AD led to speculation that the genetic abnormality might be located on chromosome 21. People with Down's syndrome commonly develop the neuropathological stigmata of AD between the ages of 35 and 45 , and the prevalence of Down's syndrome is reported to be increased among relatives of probands with AD (Oliver \& Holland, 1986). Over the last few years, therefore, a considerable effort has been made to determine whether there is linkage between $\mathrm{AD}$ and gene markers for loci on chromosome 21. This has recently culminated in the demonstration of linkage by a large international group centred in Boston (St George-Hyslop et al. 1987). These investigators used several polymorphic DNA markers spanning the long arm of chromosome 21 to study the inheritance of the disease in four large pedigrees. Linkage analysis revealed that two of these probes (designated D21 S/6 and D21 S1/D21 S11) are linked to the expression of AD with a highly significant probability.

$\mathrm{AD}$, unlike many psychiatric illnesses, is associated with characteristic neuropathological findings. The molecular composition of neuritic plaques, neurofibrillary tangles and amyloid angiopathy has been the focus of much recent investigation. This work has converged strikingly upon the genetic studies. The first breakthrough was the isolation of the amyloid protein found in the core of senile plaques and in the blood vessels of those with AD. This protein, which is also abnormally deposited in Down's syndrome, has been termed A4 protein or $\beta$-amyloid. Needless to say, a good deal of excitement was generated when the gene coding for A4 protein was located on chromosome 21 close to the linked probes of the Boston group (Kang et al. 1987; Goldgaber et al. 1987; Tanzi et al. 1987). Furthermore, it has been claimed that a small portion of chromosome 21 containing the $\mathrm{A} 4$ gene is duplicated in $\mathrm{AD}$ so that, as in Down's syndrome, three copies are present (Delabar et al. 1987).

Taken together, these data represent strong circumstantial evidence that the A4 gene is the locus of the defect causing AD. However, evidence that this is not the case has come from two studies in which the A4 locus was only weakly linked to the disease. Moreover, in several families, there was recombination between the $\mathrm{A} 4$ gene and $\mathrm{AD}$ (Van Broeckhoven et al. 1987; Tanzi et al. 1987). These findings suggest that the disease locus is on the neighbouring portion of chromosome 21 .

It should be remembered that the majority of sufferers do not appear to have a family history of the disorder. These may all be sporadic cases. Alternatively, since AD is predominantly a disease of the elderly, its inheritance might be masked by the death of predisposed relatives from unrelated disease (Breitner et al. 1986). This means that genetic forms of the illness might be much more common than is at first apparent. Finally, it is to be expected that the understanding of familial disease will ultimately throw light upon the pathophysiology of sporadic cases.

\section{AFFECTIVE DISORDER}

Research into the molecular genetics of affective disorder has not benefited from a clue such as that provided for Alzheimer's disease by the association with Down's syndrome. However, much has been gained from the study of the old order Amish community in Pennsylvania. This population is highly suitable for genetic research as families are large, emigration rare and paternity relatively certain. Moreover, religious convictions proscribe the use of alcohol or drugs and thereby facilitate unambiguous diagnosis of affective disorder. Segregation analysis of data from the families of probands with bipolar disease provided evidence for a single genetic locus with autosomal dominant transmission. Initial studies of RFLPs in a large Amish pedigree using a number of probes suggested that the disease might be linked to two markers on the short arm of chromosome 11 , the insulin gene (INS) and the cellular oncogene Ha-ras-1 (HRAS 1) (Gerhard et al. 1984). These two markers have recently been employed in a more extensive study of the same pedigree which has produced quite convincing evidence for linkage (Egeland et al. 1987). This suggests that, in this pedigree at least, 
a dominant gene which confers a strong predisposition to bipolar affective disorder lies on the tip of the short arm of chromosome 11. It is of considerable interest that the structural gene for tyrosine hydroxylase is located upon the same segment of the chromosome. This enzyme catalyses an important step in the synthesis of two neurotransmitters, dopamine and noradrenaline, which have both been implicated in the pathogenesis of mental illness.

However, the generality of findings in the Amish has already been called into question by two studies, one of American and the other of Icelandic pedigrees (Detera-Wadleigh et al. 1987; Hodgkinson et al. 1987), which managed to rule out linkage of INS and HRAS 1 to bipolar affective disorder. This discrepancy is probably not due to methodological differences, but rather suggests that there is more than one gene responsible for the condition. Further support for genetic heterogeneity comes from recent studies showing linkage of bipolar illness to various $\mathrm{X}$ chromosome markers in Israeli and Belgian pedigrees (Baron et al. 1987; Mendelwicz et al. 1987). It seems likely, therefore, that there are at least three genes predisposing to bipolar disorder.

Several interesting issues arise from the demonstration of genetic heterogeneity. First, we might ask whether this is associated with clinical heterogeneity. There do not appear to have been gross clinical differences between the patients in the above studies. However, it might be possible to detect more subtle differences in symptoms or variations in course or outcome associated with different genetic defects. The second question, which might well turn out to be related to the first, concerns the degree of similarity between the various disturbances of brain function that result from the different genetic lesions. For example, each gene might code for a sub-unit of the same complex molecule, such as a receptor. Conversely, they might have quite different effects whose consequences eventually converge upon the final common pathway to affective disorder.

\section{IMPLICATIONS}

In the wake of these recent findings, study of the molecular pathology of mental illness is likely to begin in earnest. Advances have already been made in some diseases causing mental handicap and this is likely to prove an especially fruitful area for molecular genetics (Whatley et al. 1987). Research workers are also starting to focus their attention upon other psychiatric disorders with a presumed genetic component, such as schizophrenia and anxiety. This would seem, therefore, to be an appropriate time to consider some of the goals and consequences of such research.

\section{Diagnostic}

The discovery of DNA polymorphisms which are tightly linked to an illness will, in some instances, allow pre-symptomatic diagnosis. We shall discuss the implications of this by reference to the three conditions in which significant advances have already been made; Huntington's disease, Alzheimer's disease and affective disorder.

In the case of Huntington's disease, pre-symptomatic diagnosis is possible with a high degree of accuracy because the probe is tightly linked to the disease locus and there is apparently $100 \%$ penetrance. However, there are several problems. First, the test cannot be applied to everyone at risk; at least one living grandparent must be available. In one study this criterion was fulfilled for only $15 \%$ of individuals at risk (Harper, 1986). Secondly, the test is not $100 \%$ accurate because there is up to a $5 \%$ chance of recombination occurring between the marker and the disease locus. Moreover, although heterogeneity has not been demonstrated, it cannot be excluded with certainty. Thirdly, by no means all those at risk will wish to be tested as no preventive therapy can be offered. Fourthly, those identified as probable carriers of the gene might not be able to cope with the burden of this knowledge. Careful counselling and long-term support will therefore be needed (Crawfurd \& Harris, 1986). Finally, the results of such a predictive test will have implications for others, such as prospective spouses, employers and insurers, and this might lead to ethical problems (Crawfurd \& Harris, 1986). 
The marker test is likely to be more useful for pre-natal diagnosis where the foetus now represents the third generation. However, in most cases the parent will not have reached the age of risk and the test will therefore only determine whether or not the foetus has the same $50 \%$ risk as the parent (Harper, 1986). It has been argued that, given the low rate of spontaneous mutation in Huntington's disease, a combination of pre-natal diagnosis with selective termination and genetic counselling should ensure a dramatic fall in the prevalence of the disorder (Harper, 1986). However, many will wonder whether it is ethically acceptable to abort a foetus, which, even if affected, (and the odds usually will be only $50: 50$ ) could be expected to live quite healthily for upwards of $30-40$ years.

In the case of Alzheimer's disease, as we have seen, there is uncertainty about the degree of aetiological heterogeneity. In any case, the majority of sick individuals do not seem to have a family history of the disorder and it seems unlikely, therefore, that tests based upon linkage will be useful in more than a few, rare, multiply-affected families. Even if it becomes possible to detect the disease allele pre-symptomatically, this will be of little clinical value until some form of preventive therapy is available because few carriers of the disease gene will consider $50 \%$ risk to offspring of an illness of such late onset sufficient grounds to desist from reproduction. Such pre-disposed individuals will, of course, be of considerable interest to research workers concerned with the early features of the illness and in trials of prophylactic therapy. However, the ethical issues will have to be very carefully considered. As far as pre-natal diagnosis is concerned, even if a suitable test were to become available, the late onset of the disease would make termination ethically unacceptable to many.

In affective disorder, genetic heterogeneity alone will limit the usefulness of chromosome 11 markers for pre-symptomatic diagnosis. Moreover, even in the Amish pedigree penetrance is incomplete so that there is no guarantee that an individual with the disease gene will ever become unwell. In addition, the same clinical and ethical considerations apply to possible pre-symptomatic diagnosis of affective disorder that apply to Alzheimer's disease. Finally, few would consider bipolar affective disorder sufficient grounds for termination of pregnancy even if it were possible accurately to detect individuals at high risk.

\section{Therapy}

We believe that the greatest benefits that will accrue from the application of molecular genetics to mental disorder will come not from the use of markers for diagnosis but from the insights into pathological mechanisms that will result. The progressive characterization of the genome in the region of the marked locus should eventually lead to the precise identification of the genetic defect. This work is now well under way for Huntington's, Alzheimer's and affective disorder. Once a genetic abnormality has been identified it should be possible to determine its immediate biochemical consequences. From here we may hope to follow the sequence of changes that finally results in the phenotype so preparing the ground for more rational and effective therapeutic strategies.

MICHAEL J. OWEN AND STEPHEN A. WHATLEY

Professor W. A. Lishman and Drs R. M. Murray, V. L. Nimgaonkar and A. J. Holland made valuable comments on the manuscript.

\section{REFERENCES}

Baron, M., Risch, N., Hamburger, R. Mandel, B., Kushner, S., Newman, M., Drumer, D. \& Belmaker, R. H. (1987). Genetic linkage between $X$-chromosome markers and bipolar affective illness. Nature 326, 289-292.

Breitner, J. C. S., Folstein, M. F. \& Murphy, E. A. (1986). Familial aggregation in Alzheimer dementia. I. A model for the agedependent expression of an autosomal dominant gene. Journal of Psychiatric Research 20, 31-43.
Crawfurd, D. I. O. \& Harris, R. (1986). Ethics of predictive testing for Huntington's chorea: Need for more information. British Medical Journal 293, 249-251.

Delabar, J-M., Goldgaber, D., Lamour, Y., Nicole, A., Huret, J.-L., De Grouchy, J., Brown, P., Gajdusek, D. C. \& Sinet, P.-M. (1987). $B$ amyloid gene, duplication in Alzheimer's Disease and karyotypically normal Down's syndrome. Science 235, 1390-1392.

Detera-Wadleigh, S. D., Berrettini, W. H., Goldin,L. R., Boorman, 
D., Anderson, S. \& Gershon, E. S. (1987). Close linkage of CHarvey-ras-1 and the insulin gene to affective disorder is ruled out in three North American pedigrees. Nature 325, 806-808.

Egeland, J., Gerhard, D. S., Pauls, D. L. Sussex, J. N., Kidd, K. K., Allen, G. R., Hostetter, A. M. \& Howman, D. (1987). Bipolar affective disorders linked to DNA markers on chromosome 11. Nature 325, 783- 787.

Gerhard, D., Egeland, J. A., Pauls, D. L., Kidd, J. R., Kramer, P. L., Houseman, D. \& Kidd, K. K. (1984). Is a gene for affective disorder located on the short arm of chromosome 11 ? American Journal of Human Genetics 36, 35.

Goldgaber, D., Herman, M. I., McBride, W., Saffiotti, U. \& Gajdusek, D. C. (1987). Characterisation and chromosomal locilisation of a cDNA encoding brain amyloid of Alzheimer's disease. Scicnce 235, 877-880.

Gusella, J. F., Wexler, N. S., Conneally, P. M., Naylor, S. L., Anderson, M. A., Tanzi, R. E., Watkins, P. C., Ottina, K., Wallace, M. R., Sakaguchi, A. Y., Young, A. B., Shoulson, I., Bonilla, E. \& Martin, J. B. (1983). A polymorphic DNA marker genetically linked to Huntington's disease. Nature 306, 234-238.

Harper, P. S. (1986). The prevention of Huntington's chorea. Journal of the Royal College of Physicians 20, 7-14.

Hodgkinson, S., Sherrington, R., Gurling, H. M. D., Marchbanks, R., Reeders, S., Mallet, J., Mclnnes, M., Petursson, H. \& Brynjolfsson, J. (1987). Molecular genetic evidence for heterogeneity in manic depression. Nature 325, 805-806.

Kang, J., Lamaire, H-G., Unterbeck, A., Salbaum, J. M., Masters, C. L., Grzeschnik, K.-H., Multhamp, G., Beyreuther, K. \& Muller-Hill, B. (1987). The precursor of Alzheimer's disease amyloid A4 protein resembles a cell surface receptor. Nature 325, 733-736.

Mendelwicz, J., Simon, P., Sevy, S., Charon, F., Brocas, H., Legros, S. \& Vassart, G. (1987). Polymorphic DNA marker on $X$ chromosome and manic depression. Lancet i, 1230-1232.
Oliver, C. \& Holland, A. J. (1986). Down's syndrome and Alzheimer's disease: a review. Psychological Medicine 16, 307-322.

St. George-Hyslop, P. H., Tanzi, R. E., Polinsky, R. J., Haines, J. L., Nee, L., Watkins, P. C., Myers, R. H., Feldman, R. G., Pollen, D., Drachman, D., Growdon, J., Bruni, A., Foncin, J.-F., Salmon, D., Frommelt, P., Amaducci, L., Sorbi, S., Piacentini, S., Stewart, G. D., Hobbs, W. J., Conneally, P. M. \& Gusella, J. F. (1987). The genetic defect causing familial Alzheimer's disease maps on chromosome 21. Science 235, 885-890.

Tanzi, R. E., Gusella, J. F., Watkins, P. C. Bruns, G. A. P., St. George Hyslop, P., Van Keuren, M., Patterson, D., Pagan, S., Kurnit, D. M. \& Neve, R. L. (1987). Amyloid B protein gene: cDNA, mRNA distribution and genetic linkage near the Alzheimer locus. Science 235, 880-884.

Tanzi, R. E., St George-Hyslop, P., Heines, J. L., Polinsky, R. L., Nee, L., Fonzin, J.-F., Neve, R. L., McClatchey, A. L., Conneally, P. M. \& Gusella, J. F. (1987). The genetic defect in familial Alzheimer's disease is not tightly linked to the amyloid $\beta$-protein gene. Nature 329, 156-157.

Van Broeckhoven, C., Genthe, A. M., Vandenberghe, A., Backhoven, S. H., Raeymaekers, P., Wehnert, A., Ghevens, J., Cras, P., Bruyland, M., Martin, J. J., Norsthembe, B., Salbaum, M., Multhamp, P., Masters, C. L., Muller-Hill, B., Beyreuther, K., Gurling, H. M. D., Mullan, M. J., Holland, A., Barton, A., Irving, N., Willıamson, R., Rıchards, S. J. \& Hardy, J. A. (1987). Failure of Alzheimer's disease to segregate with the A4 amyloid gene in several European families. Nature 329, 154-155.

Whatley, S. A., Owen, M. J. \& Murray, R. M. (1987). Neuropsychiatric disorders in the new genetics. In Bridges Between Neurology and Psychiarry (ed. E. H. Bridges and M. R. Trimble). Churchill Livingstone: Edinburgh. 